\title{
Effect of Different Zilpaterol Hydrochloride Levels and Feeding Methods on the Growth Performance, Carcass Traits and Blood Parameters of Male Japanese Quails \\ During Two Weeks of the Finishing Period
}

-Author(s)

Mohammadi-Arekhlo $\mathrm{M}^{\prime}$
Towhidi $\mathrm{A}^{\prime}$
Moravej $\mathrm{H}^{\prime}$
Sharafi $\mathrm{M}^{\prime \prime}$

Department of Animal Science, Faculty of Agricultural Science and Engineering, University of Tehran, Karaj.

" Department of Poultry Science, College of Agriculture, Tarbiat Modares University, Tehran.

\section{Mail Address}

Corresponding author e-mail address Mohsen Sharafi

Department of Poultry Science, College of Agriculture, Tarbiat Modares University, Tehran.

Ph: 00982148292348

Fax: 00982148292055

Email: m.sharafi@modares.ac.ir

\section{- Keywords}

$\beta$-adrenergic agonists, body weight, meat quality, Japanese quails.

\section{ABSTRACT}

The objective of this study was to determine the effects of different zilpaterol hydrochloride (ZH) levels and feeding methods on the growth performance and carcass traits of Japanese quails. In this trial, 224 male quails with 34 days of age were distributed into seven treatments. A factorial arrangement with three $\mathrm{ZH}$ levels $(0.2$, 0.225 , and $0.25 \mathrm{mg}$ zilpaterol $/ \mathrm{kg}$ of live weight $\left.{ }^{-1}\right) \times$ two feeding methods (ZH supplementation daily or every two days) plus a control treatment (no $\mathrm{ZH}$ supplementation) was applied. The weight gain of birds fed ZH every two days was significantly higher than those fed $\mathrm{ZH}$ daily during the period of $41-47$ days $(p=0.03)$. During the period of 34-40 days, ZH-supplemented birds presented higher weight gain $(p<0.001)$ and better feed conversion ratio $(p=0.005)$ compared with the control group. Moisture, protein, ash, and cholesterol levels of the combination of breast and leg were not affected $(p \geq 0.10)$ by zilpaterol supplementation. Leg muscle fat and protein contents of control birds were higher and lower compared with $\mathrm{ZH}$-supplemented birds, respectively ( $p=0.002$ and $p=0.05)$. In conclusion, $Z H$ supplementation in the diet of male Japanese quail improved growth performance during the finishing period (34-40d), and the most economical level of $\mathrm{ZH}$ is $0.2\left(\mathrm{mg} / \mathrm{kg}\right.$ of $\left.\mathrm{LW}^{-1} \mathrm{~d}^{-1}\right)$, when supplemented every two days.

\section{INTRODUCTION}

The $\beta$-adrenergic agonists ( $\beta$-AA) improves the efficiency of gain and affects carcass characteristics and meat quality of several animal species (Avendano-Reyes et al., 2006). These compounds reduce adipose tissue deposition and increase muscle mass in domestic species, such as pigs (Apple et al., 2008; Carr et al., 2005; Poletto et al., 2009), beef cattle (Allen et al., 2009; Gruber et al., 2007) and poultry (Schiavone et al., 2004). These compounds also stimulate adipocyte triacylglycerol degradation and inhibit fatty acid and triacylglycerol synthesis (Mersmann, 1998). Zilpaterol hydrochloride (ZH) is a pharmaceutical beta-adrenergic agonist ( $\beta-A A)$ commercially available in Mexico, U.S.A, Australia, New Zealand, Brazil, Indonesia, and the Republic of South Africa under the name of Zilmax (Intervet Inc.). ZH was approved in the United States by the Center for veterinary medicine in 2006 (FDA, 2006), because it is rapidly eliminated and safe when adequately used (Lopez-Carlos et al., 2010). Synthetic $\beta$-AA are chemically and pharmacologically similar to the natural catecholamines dopamine, norepinephrine, and epinephrine (Vasconceloset al., 2008). Moody et al. (2000) mentioned that the $\beta$-AA compounds differ in potency, since cells and tissues vary in expression of $\beta$-adrenergic receptor types, and in consequence, their effects are also associated with the type of $\beta$ agonist, species treated, and dose and duration of treatment. In this regard, Kim et al. (1987) reported that cimaterol, a $\beta$-AA, improved the 
daily gain of lambs during the first 6 weeks of rearing, whereas Pringle et al. (1993) found that L644,969, a type of $\beta-A A$, improved daily gain of lambs only during the first 2 weeks, and dressing percentage during the first 4 weeks of feeding.

In our literature review, we did not find any published data on the effect of $\mathrm{ZH}$ on the growth performance of avian species. Therefore, this study aimed at evaluating the effects of three dietary levels of $\mathrm{ZH}$ and two methods $\mathrm{ZH}$ feeding methods on the growth performance, carcass traits, and blood parameters of Japanese quails.

\section{MATERIALS AND METHODS}

\section{Facilities and birds}

One thousand Japanese quails ( $1 \mathrm{~d}$ old) were reared in a temperature-controlled room on the floor until 34 days of age. Then, 224 male Japanese quails with similar average of live body weight were randomly assigned to 28 battery cages according to a completely randomized block design with seven treatments and four replicates (cage) of eight birds per experimental unit. Room temperature was maintained at $36-38^{\circ} \mathrm{C}$ for the first $3 \mathrm{~d}$, and was then reduced by $3^{\circ} \mathrm{C}$ weekly until reaching $23-24^{\circ} \mathrm{C}$. Continuous light was provided.

\section{Diets and experimental design}

The finisher diet was were based on corn and soybean meal and its composition is shown in Table 1. Birds were fed diets with three different doses of zilpaterol (0.2 (D1), 0.225 (D2), or 0.25 (D3) $\mathrm{mg}$ zilpaterol $/ \mathrm{kg}$ of live weight ${ }^{-1}$ ) for 14 days of the finishing period by two methods: zilpaterol (M1) was fed daily or every two days (M2). A control group was established, in which the birds did not receive any ZH supplementation. Zilpaterol hydrochloride was withdrawn three days prior to slaughter.

\section{Data collection}

Body weight and feed intake were recorded at weekly intervals. At the end of the finishing period, when broilers were 50 days of age, birds were submitted to $12 \mathrm{~h}$ of feed withdrawal, eight birds (two birds which body weight was similar to the average in each replicate) per treatment were sacrificedby severing the right carotid artery and jugular vein. After bleeding, birds were processed and dissected by a trained team. The heads and necks were removed by cutting through the last cervical and the first thoracic vertebrae, and the shank at the tibiotarsal-metatarsal joints Vidyadaran et
Table 1 - Ingredients and calculated composition of the basal diet (as-fed basis)

\begin{tabular}{ll}
\hline Item & Ingredient (\%) \\
\hline Corn & 56.09 \\
Soybean meal & 32.43 \\
\hline Gluten meal & 8.00 \\
\hline Calcium co3 & 1.29 \\
\hline Dicalcium phosphate & 0.94 \\
\hline Salt & 0.34 \\
\hline DL-Methionine & 0.14 \\
\hline L-Lysine & 0.27 \\
\hline Vitamin premix1 & 0.25 \\
\hline Mineral premix 2 & 0.25 \\
\hline Total & 100.00 \\
Calculated value & \\
\hline ME (kcal/kg) & 2900 \\
\hline CP (\%) & 24 \\
\hline Methionine (\%) & 0.5542 \\
Met+Cys & 0.75 \\
\hline Lysine (\%) & 1.3 \\
\hline Ca (\%) & 0.8024 \\
\hline Available P (\%) & 0.3017 \\
\hline Sodium & 0.15 \\
\hline
\end{tabular}

al. (1988). Carcass dressing percentage was calculated as carcass weight (without blood, feathers, head, neck, shank, or giblets) relative to live weight. Liver, abdominal fat, legs, and breast were weighed and kept at $-20^{\circ} \mathrm{C}$ for chemical composition determination.

\section{Carcass chemical analyses}

Leg and breast chemical composition was determined as described by the AOAC (1990). The skin and the subcutaneous fat were removed. The muscles of the right breast and leg were carefully dissected, homogenized using a blender, and the analyzed for total moisture, ash, crude protein, crude fat, and cholesterol contents. The left breast and leg muscles were separately analyzed for crude protein and crude fat contents. In order to determine total cholesterol content of the muscles, tissue samples were thawed and extracted with 2:1 chloroform: methanol (Bligh \& Deyer, 1959). Total cholesterol levels were then enzymatically determined by the method of Allain et al. (1974).

\section{Blood samples collection and analysis}

Individual blood samples were collected during bleeding, and immediately centrifuged at 3500 rpm for $15 \mathrm{~min}$. Plasma was harvested after centrifugation of the clotted blood, stored at $-20^{\circ}$ cin a deep freezer until the time of chemical determinations. Blood biochemical parameters were enzymatically determined using commercial kits. 


\section{Statistical analysis}

At first, data of all treatments were analyzed without control group according to a completely randomized block design in a 3 (levels of $\mathrm{ZH}) \times 2$ (feeding method) factorial arrangement, using cages as blocks. At the second step, in order to compare the averages of the treatments with the control treatment, data were analyzed according to a randomized block design using the GLM procedure of SAS. Means were compared using Duncan's test at significance level of $p<0.05$.

\section{RESULTS AND DISCUSSION}

The main effects of doses and methods ( $D$ \& M) and their interactions on growth performance during the two last finishing weeks were shown in Table 2. Significant dose $x$ method interactions were observed for feed intake during the period of days 34-40. The highest feed intake was obtained in group D2 $x$
M1.There were significant weight gain differences between $\mathrm{M} 1$ and $\mathrm{M} 2$ when birds were fed zilpaterolon days 41-47 ( $p=0.03)$, with M2 birds presenting higher weight gain than M1 birds. In this regard, Moloney et al. (1991) stated that extended time of $\beta$-adrenergic use during the finishing period may cause $\beta$-adrenergic receptor desensitization and down regulation, thereby reducing growth rate responses. In addition, pig studies indicate that intermittent use of ractopamine may help reducing this negative effect on performance because of the resting time given to the receptors $\mathrm{Dib}$ et al. (2010).It seems that in our trial, the $M 2$ method reduced the down regulation of the $\beta$-adrenergic receptor. In fact, we suppose that the higher weight gain obtained with the M2 method on days 41-47 may be due to the up regulation of the $\beta$-adrenergic receptor during the two days the product was not fed after two days of feeding. The effect of zilpaterol supplementation on the growth performance of the treated and control groups reshown in Table 2 .

Table 2 - Main effects and interactions of doses and methods of zilpaterol supplementation on thebody weight (BW), feed intake (FI), and feed conversion ratio (FCR)ofJapanese quails and comparison with the control group.

\begin{tabular}{|c|c|c|c|c|c|c|}
\hline \multirow[b]{2}{*}{ Item } & \multicolumn{3}{|c|}{$34-40 d$} & \multicolumn{3}{|c|}{$41-47 d$} \\
\hline & BW (g) & $\mathrm{Fl}(\mathrm{g})$ & FCR & BW (g) & $\mathrm{Fl}(\mathrm{g})$ & FCR \\
\hline \multicolumn{7}{|l|}{ ZH doses } \\
\hline$D_{1}$ & 47.91 & 174.18 & 3.66 & 25.78 & 198.95 & 7.81 \\
\hline$D_{2}$ & 49.54 & 175.71 & 3.58 & 26.45 & 197.58 & 7.65 \\
\hline$D_{3}$ & 47.35 & 172.04 & 3.6 & 24.56 & 193 & 8.01 \\
\hline SEM & 0.89 & 1.59 & 0.08 & 1.45 & 3.67 & 0.35 \\
\hline P (value) & 0.22 & 0.28 & 0.77 & 0.65 & 0.5 & 0.78 \\
\hline \multicolumn{7}{|c|}{ Feeding method } \\
\hline$M_{1}$ & 48.58 & 173.65 & 3.58 & 23.7 & 192.79 & 8.2 \\
\hline$M_{2}$ & 47.96 & 174.31 & 3.65 & 27.48 & 200.22 & 7.44 \\
\hline SEM & 0.72 & 1.29 & 0.06 & 1.19 & 3.0 & 0.29 \\
\hline$P$ (value) & 0.55 & 0.72 & 0.49 & 0.03 & 0.09 & 0.07 \\
\hline \multicolumn{7}{|c|}{ Doses $\times$ Method } \\
\hline$D_{1} M_{1}$ & $47.81^{\mathrm{ab}}$ & $171.53^{B}$ & $3.59^{b}$ & 23.91 & 197.87 & 8.37 \\
\hline$D_{1} M_{2}$ & $48.02^{\mathrm{ab}}$ & $176.8^{\mathrm{AB}}$ & $3.73^{b}$ & 27.66 & 200.03 & 7.25 \\
\hline $\mathrm{D}_{2} \mathrm{M}_{1}$ & $51.47^{a}$ & $179.43^{A}$ & $3.55^{b}$ & 23.81 & 193.45 & 8.19 \\
\hline $\mathrm{D}_{2} \mathrm{M}_{2}$ & $47.62^{\mathrm{ab}}$ & $172^{\mathrm{B}}$ & $3.61^{b}$ & 29.09 & 201.72 & 7.12 \\
\hline $\mathrm{D}_{3} \mathrm{M}_{1}$ & $46.47^{b}$ & $170^{B}$ & $3.60^{b}$ & 23.40 & 187.06 & 8.06 \\
\hline $\mathrm{D}_{3} \mathrm{M}_{2}$ & $48.25^{\mathrm{ab}}$ & $174.1^{\mathrm{AB}}$ & $3.60^{\mathrm{b}}$ & 25.71 & 198.94 & 7.96 \\
\hline SEM & 1.25 & 2.25 & 0.11 & 2.06 & 5.2 & 0.5 \\
\hline $\mathrm{P}$ (value) & 0.09 & 0.02 & 0.85 & 0.77 & 0.64 & 0.5 \\
\hline Control & $40.5^{c}$ & 171.8 & $4.25^{a}$ & 23.79 & 191.9 & 8.06 \\
\hline SEM & 1.23 & 0.11 & 2.31 & 1.92 & 5.27 & 0.47 \\
\hline$p$ (value) & $<0.001$ & 0.09 & 0.005 & 0.27 & 0.45 & 0.42 \\
\hline
\end{tabular}

D1, 2, 3: $(0.2,0.225,0.25 \mathrm{mg} / \mathrm{kg}$ of LW-1 d-1 zilpaterol, respectively)

M1: received zilpaterol daily; M2: received zilpaterol every two days

Control: diet with no ZH supplementation

$\mathrm{D} 1,2,3 \& \mathrm{M} 1,2$, : effect of the interaction between $\mathrm{D}$ and $\mathrm{M}$ in the different treatments.

abc Means in the same column without a common superscript letter are different when groups receiving ZH were compared with thecontrol group $(p<0.05)$.

$A B$ Means in the same column without a common superscript letter are different, showing effects of the interaction between ZH dose and feeding method ( $p<0.05)$. 
Zilpaterol supplementation improved weight gain $(p=0.0003)$ and feed conversion ratio $(p=0.005)$ in all treatments compared with the control group, but it did not affect feed intake on days 34-40 ( $p=0.09)$. However, on days 41-47 days, zilpaterol did not significantly affect growth performance. There are some reports about different effects of $\beta$-agonists on the growth performance of animals. Ansari-Pirsaraei et al. (2007) demonstrated that terbutaline did not affect daily weight gain, but reduced feed conversion ratio (FCR) of male broilers when 5 and $10 \mathrm{mg} / \mathrm{kg}$ were fed, respectively. On the other hand, in some studies, ZH supplementation increased average daily gain and gain efficiency in feedlot lambs (Estrada-Angulo et al., 2008), steers (Avendano-Reyes et al., 2006) and cattle (Vasconcelos et al., 2008). However, Felix et al. (2005) did not observe any effect of $\mathrm{ZH}$ supplementation on the growth performance of Pelibuey lambs. The reasons why no performance differences were observed on days 41-47 days between birds receiving $\mathrm{ZH}$ and the control group may be bird maturity and hormonal changes. Another reason for this phenomenon is that the B-AA receptor in the target tissues may be rapidly inactivated, or a particular species may have a limited number of B-AA receptors in the target tissues, reducing the response to the agonist (Mersmann, 1998). Perhaps the Japanese quail is one the species that has a limited number of receptors.

Table 3 shows that, when the zilpaterol supplemented groups were compared, carcass traits were not influenced by the treatments or their interactions. However, leg weight was higher in $\mathrm{ZH}$-fed chickens (D1 and D2 of M1, D1 and D3 of M2) than in control group $(p=0.01)$, but the weights of the other parts

Table 3 - Main effects and interactions of doses and methods of zilpaterol supplementation on carcass and parts weight and yield of Japanese quails and comparison with the control group.

\begin{tabular}{|c|c|c|c|c|c|c|c|c|c|}
\hline \multirow[b]{2}{*}{ Item } & \multirow[b]{2}{*}{ Carcass } & \multirow[b]{2}{*}{ Breast } & \multicolumn{3}{|c|}{ Weight(g) } & \multicolumn{4}{|c|}{ Yield } \\
\hline & & & Leg & Liver & $A F^{*}$ & Breast & Leg & Liver & $A F^{*}$ \\
\hline \multicolumn{10}{|l|}{ ZHdoses } \\
\hline D1 & 161 & 64.9 & 36.7 & 3.73 & 2.95 & 40.1 & 22.7 & 2.3 & 1.81 \\
\hline D2 & 163 & 65.1 & 36.5 & 4.05 & 3.05 & 39.8 & 22.3 & 2.48 & 1.89 \\
\hline D3 & 159 & 63 & 35.9 & 3.83 & 3.11 & 39.6 & 22.6 & 2.4 & 1.97 \\
\hline SEM & 3.61 & 1.77 & 0.76 & 0.19 & 0.25 & 0.6 & 0.34 & 0.12 & 0.16 \\
\hline P(value) & 0.68 & 0.66 & 0.74 & 0.48 & 0.89 & 0.84 & 0.76 & 0.59 & 0.78 \\
\hline \multicolumn{10}{|l|}{ Method } \\
\hline M1 & 163 & 66.2 & 36.7 & 3.96 & 3.1 & 40.5 & 22.5 & 2.43 & 1.91 \\
\hline M2 & 159.7 & 62.53 & 36.1 & 3.78 & 2.98 & 39.1 & 22.6 & 2.37 & 1.87 \\
\hline SEM & 2.95 & 1.45 & 0.62 & 0.15 & 0.21 & 0.49 & 0.28 & 0.1 & 0.13 \\
\hline p (value) & 0.4 & 0.09 & 0.47 & 0.41 & 0.69 & 0.06 & 0.89 & 0.64 & 0.81 \\
\hline \multicolumn{10}{|c|}{ doses×Method } \\
\hline D1M1 & 164.4 & 67.9 & $37.6 a$ & 3.68 & 3.31 & 41.37 & 22.94 & 2.23 & 2.00 \\
\hline D1M2 & 159.5 & 61.95 & $36.5 a$ & 3.78 & 2.58 & 48.83 & 22.89 & 2.38 & 1.61 \\
\hline D2M1 & 167.1 & 67.41 & $37.5 a$ & 4.25 & 2.90 & 40.31 & 22.52 & 2.56 & 1.76 \\
\hline $\mathrm{D} 2 \mathrm{M} 2$ & 159.73 & 62.72 & $36.0 a b$ & 3.85 & 3.21 & 39.27 & 22.58 & 2.41 & 2.01 \\
\hline D3M1 & 158.2 & 63.13 & $36.1 \mathrm{ab}$ & 3.96 & 3.08 & 39.93 & 22.89 & 2.50 & 1.96 \\
\hline D3M2 & 159.8 & 62.91 & $36.55 a$ & 3.7 & 39.30 & 3.15 & 22.88 & 2.31 & 1.97 \\
\hline SEM & 5.1 & 2.5 & 1.08 & 0.27 & 0.36 & 0.85 & 0.49 & 0.17 & 0.23 \\
\hline p (value) & 0.67 & 0.49 & 0.54 & 0.62 & 0.34 & 0.52 & 0.95 & 0.58 & 0.39 \\
\hline Control & 157.5 & 61.4 & $34.45 b$ & 3.91 & 3.92 & 38.99 & 21.78 & 2.48 & 2.49 \\
\hline SEM & 4.75 & 2.33 & 0.54 & 0.26 & 0.34 & 0.82 & 0.48 & 0.16 & 0.21 \\
\hline p (value) & 0.76 & 0.3 & 0.01 & 0.76 & 0.23 & 0.34 & 0.71 & 0.83 & 0.2 \\
\hline
\end{tabular}

$D_{1,2,3}:\left(0.2,0.225,0.25 \mathrm{mg} / \mathrm{kg}\right.$ of $\mathrm{LW}^{-1} \mathrm{~d}^{-1}$ zilpaterol, respectively)

$\mathrm{M}_{1}$ : received zilpaterol daily; $\mathrm{M}_{2}$ : received zilpaterol every two days

Control: diet with no ZH supplementation

$D_{1,2,3} \& M_{1,2}$ : effect of the interaction between $D$ and $M$ in the different treatments.

abc Means in the same column without a common superscript letter are different when groups receiving $\mathrm{ZH}$ were compared with the control group $(p<0.05)$.

*Abdominal fat 
were not significantly different $(p>0.05)$. This finding is in agreement with the results of Morgan et al. (1989), which obtained heavier legs in chickens fed with cimaterol. However, in some cases, $\beta$-agonist supplementation did not affect carcass weight or dressing percentage (Koohmaraie et al., 1991). This disparity in responses may be due to the fact that a given agonist may not activate the target tissue receptors as well in one species as in another. The possible mechanisms include agonist affinity for the receptor(s), coupling of the agonist-receptor complex to the signal transduction system, and factors that influence delivery of the compound to the receptor sites (Mersmann, 1998).

In this study, plasma glucose and cholesterol levels were not influenced $(p<0.05)$ by the administration of $\beta$-AA (Table 4). These results are consistent with the previous report of Lopez-Carlos et al. (2010), but opposed to those found by Ansari-Pirsaraei etal. (2007). Plasma cholesterol decreased in chickens treated with

Table 4 - Main effects and interactions of doses and methods of zilpaterol supplementation on blood parameters of Japanese quails and comparison with the control group.

\begin{tabular}{|c|c|c|}
\hline Item & Glucose(mg/dL) & Cholesterol(mg/dL) \\
\hline \multicolumn{3}{|l|}{$\mathrm{ZH}$ doses } \\
\hline$D_{1}$ & 354 & 183 \\
\hline $\mathrm{D}_{2}$ & 342 & 176 \\
\hline$D_{3}$ & 345 & 184 \\
\hline SEM & 7.85 & 4.69 \\
\hline $\mathrm{p}$ (value) & 0.54 & 0.42 \\
\hline \multicolumn{3}{|l|}{ Method } \\
\hline$M_{1}$ & 351 & 183 \\
\hline$M_{2}$ & 343 & 179 \\
\hline SEM & 6.4 & 3.82 \\
\hline P (value) & 0.37 & 0.47 \\
\hline \multicolumn{3}{|c|}{ Doses $\times$ Method } \\
\hline $\mathrm{D}_{1} \mathrm{M}_{1}$ & 369 & 191 \\
\hline $\mathrm{D}_{1} \mathrm{M}_{2}$ & 335 & 174 \\
\hline $\mathrm{D}_{2} \mathrm{M}_{1}$ & 344 & 175 \\
\hline $\mathrm{D}_{2} \mathrm{M}_{2}$ & 341 & 176 \\
\hline $\mathrm{D}_{3} \mathrm{M}_{1}$ & 339 & 181 \\
\hline $\mathrm{D}_{3} \mathrm{M}_{2}$ & 351 & 186 \\
\hline SEM & 11.01 & 6.63 \\
\hline $\mathrm{p}$ (value) & 0.15 & 0.24 \\
\hline Control & 344 & 176 \\
\hline SEM & 10.44 & 6.64 \\
\hline $\mathrm{p}$ (value) & 0.36 & 0.46 \\
\hline
\end{tabular}

$D_{1,2,3}:\left(0.2,0.225,0.25 \mathrm{mg} / \mathrm{kg}\right.$ of $\mathrm{LW}^{-1} \mathrm{~d}^{-1}$ zilpaterol, respectively)

$\mathrm{M}_{1}$ : received zilpaterol daily; $\mathrm{M}_{2}$ : received zilpaterol every two days

Control: diet with no ZH supplementation

$D_{1,2,3} \& M_{1,2}$ : effect of the interaction between $D$ and $M$ in the different treatments.

abc Means in the same column without a common superscript letter are different when groups receiving $\mathrm{ZH}$ were compared with the control group $(\mathrm{p}<0.05)$. dopamine in another experiment (Buyse et al., 1991). Responses to various B-AA vary with age, species, sex, diet, breed, dose and duration of treatment, which may be due to stimulation of different receptors (Beermann, 2002).

Table 5 shows the main effects and interactions between doses and methods of zilpaterol supplementation on the composition of breast and leg muscle in Japanese quails. There were no significant differences among $\mathrm{ZH}$-supplementation treatments. However, as seen in Table 5, the fat and protein contents of the leg muscle in control group were higher and lower compared with the $\mathrm{ZH}$ treatments, respectively $(p=0.002$ and $p=0.05)$. This finding is in agreement with the results of Morgan et al. (1989) with broiler chickens treated by cimaterol. Zilpaterol may affect muscle fat content by two mechanisms. The first is related with the activation of $\beta$-adrenergic receptors, resulting in an increase in the number of CAMP and higher lipolysis rate in the fat tissue, thereby reducing muscle fat content. The second mechanism is related with the phosphorylation of protein kinase $A$ and then deactivation of acetyl COA carboxylase, reducing lipogenesis rate. On the other hand, $\mathrm{ZH}$ may increase muscle protein content by increasing the biosynthesis of intracellular protein. Watson-Wright \& Wilkinson(1986)reported that skeletal muscle has beta-2 subclass receptors, but that receptor density is a function of muscle type. White fibers appear to have low beta-receptor density, whereas red fibers contain high beta-receptor density. The lack of response in the breast muscle to $\mathrm{ZH}$ treatment in the present experiment could be partially due to the higher proportion of white fibers in the breast muscle relative to leg muscle. The percentage of moisture, protein, ash, and cholesterol in the breast and leg muscles were not affected $(p \geq 0.10)$ by zilpaterol. Out results are consistent with those of Dawson et al. (1997), who supplemented beef steers with other $\beta-A A$ and did not find any effects on carcass ash percentage.

In conclusion, ZH supplementation in the diet of male Japanese quail improved growth performance during the finishing period (34-40d), and the most economical level of $\mathrm{ZH}$ is $0.2\left(\mathrm{mg} / \mathrm{kg}\right.$ of $\left.\mathrm{LW}^{-1} \mathrm{~d}^{-1}\right)$, when supplemented every two days.

\section{ACKNOWLEDGMENTS}

The authors express their gratitude to University of Tehran for providing the equipment and facilities to perform this trial. 
Table 5 - Main effects and interactions of doses and methods of zilpaterol supplementation on muscle composition (\%) of Japanese quails and comparison with the control group.

\begin{tabular}{|c|c|c|c|c|c|c|c|c|c|}
\hline \multicolumn{6}{|c|}{ Leg and breast \% } & \multicolumn{2}{|c|}{ Breast muscle \% } & \multicolumn{2}{|c|}{ Leg muscle\% } \\
\hline Item & Moisture & Fat & $\mathrm{CP}$ & Ash & Cholesterol $\mu \mathrm{g} / \mathrm{ml})$ & Fat & $\mathrm{CP}$ & Fat & $C P$ \\
\hline \multicolumn{10}{|l|}{ ZH doses } \\
\hline$D_{1}$ & 73.26 & 2.19 & 21.92 & 1.59 & 162 & 2.06 & 23.09 & 2.42 & 20.56 \\
\hline$D_{2}$ & 73.25 & 2.42 & 22.08 & 1.6 & 151 & 2.03 & 23.09 & 2.56 & 20.66 \\
\hline$D_{3}$ & 73.43 & 2.16 & 21.88 & 1.59 & 136 & 1.99 & 22.94 & 2.38 & 20.65 \\
\hline SEM & 0.22 & 0.13 & 0.13 & 0.06 & 11.23 & 0.1 & 0.08 & 0.06 & 0.06 \\
\hline P (value) & 0.82 & 0.33 & 0.49 & 0.99 & 0.29 & 0.86 & 0.3 & 0.09 & 0.47 \\
\hline \multicolumn{10}{|l|}{ Method } \\
\hline$M_{1}$ & 73.43 & 2.31 & 21.9 & 1.6 & 154 & 2.04 & 23.03 & 2.46 & 20.64 \\
\hline $\mathrm{M}_{2}$ & 73.21 & 2.20 & 22.01 & 1.6 & 145 & 2.02 & 23.04 & 2.44 & 20.62 \\
\hline SEM & 0.18 & 0.11 & 0.11 & 0.49 & 9.2 & 0.08 & 0.06 & 0.05 & 0.05 \\
\hline$p$ (value) & 0.4 & 0.49 & 0.56 & 0.89 & 0.48 & 0.85 & 0.95 & 0.75 & 0.73 \\
\hline \multicolumn{10}{|c|}{ Doses $\times$ Method } \\
\hline $\mathrm{D}_{1} \mathrm{M}_{1}$ & 73.1 & 2.36 & 21.7 & 1.62 & 169 & 2.1 & 23.09 & $2.55^{b}$ & $20.57^{\circ}$ \\
\hline$D_{1} M_{2}$ & 73.43 & 2.02 & 22.13 & 1.56 & 155 & 2.02 & 23.08 & $2.30^{\mathrm{b}}$ & $20.56^{\circ}$ \\
\hline $\mathrm{D}_{2} \mathrm{M}_{1}$ & 73.55 & 2.33 & 22.05 & 1.54 & 156 & 2.01 & 23.10 & $2.49^{b}$ & $20.67^{\circ}$ \\
\hline $\mathrm{D}_{2} \mathrm{M}_{2}$ & 72.96 & 2.51 & 22.10 & 1.65 & 146 & 2.05 & 23.08 & $2.64^{b}$ & $20.65^{\circ}$ \\
\hline $\mathrm{D}_{3} \mathrm{M}_{1}$ & 73.63 & 2.24 & 21.94 & 1.63 & 138 & 2.00 & 22.91 & $2.36^{b}$ & $20.67^{a}$ \\
\hline $\mathrm{D}_{3} \mathrm{M}_{2}$ & 73.22 & 2.07 & 21.80 & 1.55 & 133 & 1.97 & 22.96 & $2.4^{b}$ & $20.63^{\circ}$ \\
\hline SEM & 0.31 & 0.19 & 0.19 & 0.85 & 15.88 & 0.14 & 0.11 & 0.08 & 0.08 \\
\hline $\mathrm{p}$ (value) & 0.32 & 0.41 & 0.35 & 0.53 & 0.96 & 0.92 & 0.94 & 0.06 & 0.98 \\
\hline Control & 73.23 & 2.7 & 21.88 & 1.53 & 1.42 & 2.15 & 22.98 & $3.06^{a}$ & $20.28^{b}$ \\
\hline SEM & 0.35 & 0.2 & 0.17 & 0.8 & 0.15 & 0.14 & 0.12 & 0.11 & 0.08 \\
\hline $\mathrm{p}$ (value) & 0.69 & 0.26 & 0.6 & 0.91 & 0.7 & 0.97 & 0.89 & 0.002 & 0.05 \\
\hline
\end{tabular}

D1, 2, 3: $(0.2,0.225,0.25 \mathrm{mg} / \mathrm{kg}$ of LW-1 d-1 zilpaterol, respectively)

$\mathrm{M}_{1}$ : received zilpaterol daily; $\mathrm{M}_{2}$ : received zilpaterol every two days

Control: diet with no ZH supplementation

$D_{1,2,3} \& M_{1,2}$; effect of the interaction between $D$ and $M$ in the different treatments.

abc Means in the same column without a common superscript letter are different when groups receiving ZH were compared with the control group $(p<0.05)$.

\section{REFERENCES}

Allain CC, Poon LS, Chan CSG, Richmond W, Fu PC. Enzymatic determination of total serum cholesterol. Clinical Chemistry 1974;20:470-475.

Allen JD, Ahola JK, Chahine M, Szasz JI, Hunt CW, Schneider CS, et al. Effect of pre slaughter feeding and ractopamine hydrochloride supplementation on growth performance, carcass characteristics, and end product quality in market dairy cows. Journal of Animal Science 2009;87:2400-2408

Ansari-pirsaraei Z, Abolghasemi AH, Jafari-Sayadi AR, Jalali-Hajiabadi MA. Effect of terbutaline feeding on some blood parameters and carcass characteristics in broiler chicks. Proceedings of the 16th European Symposium on Poultry Nutrition;2007; Strasbourg. France. p. 483-486.

Apple JK, Maxwell CV, Kutz BR, Rakes LK, Sawyer JT, Johnson ZB, Armstrong TA, Carr, SN, Matzat PD. Interactive effect of ractopamine and dietary fat source on pork quality characteristics of fresh pork chops during simulated retail display. Journal of Animal Science 2008;86:2711-2722.

AOAC. Official Methods of analysis association of Official Analytical Chemists. Arlington; 1990.

Avendano-Reyes L, Torress-Rodriguez V, Meraz-Murillo FJ, Perez-Linares C, Figueroa-Saavedra F, Robinson PH. Effects of two beta-adrenergic agonists on finishing performance, carcass characteristics, and meat quality of feedlot steers. Journal of Animal Science 2006;84:32593265.
Beermann, DH. Beta-Adrenergic receptor agonist modula-tion of skeletal muscle growth. Journal of Animal Science 2002;80:(E. suppl. 1):E18-E23.

Bligh EG, Dyer WJ. A rapid method of total lipid extraction and purification. Canadian Journal of Biochemistry and Physiology 1959;.37:911-917.

Buyse J, Decuypere E, Huyghebaert G, Herremans M. The effect of clenbuterol supplementation on growth performance and plasma hormone and metabolite levels of broilers. Poultry Science 1991;70:993-1002.

Carr SN, Ivers J, Anderson DB, Jones DJ, Mowrey DH, England MB, et al. The effects of ractopamine hydrochloride on lean carcass yields and pork quality characteristics. Journal of Animal Science 2005;83:28862893.

Dawson JM, Soar JB, Buttery PJ, Craigon J, Gill M, Beever DE. The effect of immunization against somatostatin and $\beta$-agonist administration alone and in combination on growth and carcass composition in young steers. Journal of Animal Science 1997;64:37-57.

Dib MG. Strategies for beef cattle adaptation to finishing diets, Ractopamine hydrochloride utilization and mature size genetic selection. [thesis]. University of Nebraska; 2010.

Estrada-Angulo A, Barreras-Serrano A, Contreras G, Obregon JF, RoblesEstrada JC, Plascencia A, et al. Influence of level of zilpaterol hydrochloride supplementation on growth performance and carcass characteristics of feedlot lambs. Small Ruminant Research 2008;80:107110. 
Felix A, Estrada-Angulo A, Rios FG, Ramos CH, Perez AB. Effect of Zilpaterol clorhidrate on growth performance and carcass traits in finishing sheep. Journal of Animal Science 2005;83:63-63.

Gruber SL, Tatum JD, Engle TE, Mitchell MA, Laudert SB, Schroeder AL, et al. Effects of ractopamine supplementation on growth performance and carcass characteristics of feedlot steers differing in biological type. Journal of Animal Science 2007:85:1809-1815

Kim YS, Lee YB, Dalrymple RH. Effect of the repartitioning agent cimaterol on growth, carcass and skeletal muscle characteristics in lambs. Journal of Animal Science 1987;63:1392-1399.

Koohmaraie M, Shackelford SD, Mugglicockett NE, Stone RT. Effect of the Beta-Adrenergic Agonist L644,969 on Muscle Growth, Endogenous Proteinase Activities, and Postmortem Proteolysis in Wether Lambs. Journal of Animal Science 1991;69:4823-4835.

Lopez-Carlos MA, Ramirez R, Aguilera-Soto Jl, Arechiga CF, MendezLlorente $\mathrm{F}$, Rodriguez $\mathrm{H}$, et al. Effect of ractopamine hydrochloride and zilpaterol hydrochloride on growth, diet digestibility, intake and carcass characteristics of feedlot lambs. Livestock Science 2010;131:23-30.

Mersmann HJ. Overview of the effects of beta-adrenergic receptor agonists on animal growth including mechanisms of action. Journal of Animal Science 1998;76:160-172.

Moloney A, Allen P, Joseph R, Tarrant V. Influence of beta-adrenergic agonists and similar compounds on growth. In: Pearson AM, Dutson $T R$, editors. Growth regulation in farm animals. Advances in meat research. New York: Elsevier Applied Science; 1991. p.455-513.

Moody DE, Hancock DL, Anderson DB. Phenethanolamine repartitioning agents. Farm animal metabolism and nutrition. New York: $C A B$ International; 2000. p.65-96
Morgan JB, Jones SJ, Calkins CR. Muscle protein turnover and tenderness in broiler chickens fed cimaterol. Journal of Animal Science 1989;67:2646.

Poletto R, Rostagno MH, Richert BT, Marchant-Forde JN. Effects of a "stepup" ractopamine feeding program, sex, and social rank on growth performance, hoof lesions, and Enterobacteriaceae shedding in finishing pigs. Journal of Animal Science 2009;87:304-313.

Pringle TD, Calkins CR, Koohmaraie M, Jones SJ. Effects over Time of Feeding a Beta-Adrenergic Agonist to Wether Lambs on Animal Performance, Muscle Growth, Endogenous Muscle Proteinase Activities, and Meat Tenderness. Journal of Animal Science 1993;71:636-644.

Schiavone A, Tarantola M, Perona G, Pagliasso S, Badino P, Odore R, et al. Effect of dietary clenbuterol and cimaterol on muscle composition, betaadrenergic and androgen receptor concentrations in broiler chickens. Journal of Animal Physiology and Animal Nutrition 2004;88:94-100.

Vasconcelos JT, Rathmann RJ, Reuter RR, Leibovich J, McMeniman JP, Hales $\mathrm{KE}$, et al. Effects of duration of zilpaterol hydrochloride feeding and days on the finishing diet on feedlot cattle performance and carcass traits. Journal of Animal Science 2008; 86:2005-2015.

Vidyadaran MK, Oh BT, Mak TK, Dzulkafli J. Carcass characteristics of broilers fed with fermented cassava residue. Malaysian Appliled Biology $1988 ; 17: 39-44$

Watson-Wright WM, Wilkinson M. The muscle slice-a new preparation for the characterization of beta-adrenergic agonist binding the fast and slow twitch skeletal muscle. Muscle Nerve Journal 1986;9:416. 
